\title{
Peace Survey - Lessons Learned from Northern Ireland to Southern Thailand
}

\author{
Kayanee Chor Boonpunth ${ }^{1^{*}}$ and Mark G. Rolls ${ }^{2}$
}

${ }^{1}$ Department of Public Administration, Faculty of Management Sciences, Prince of Songkla University, Hatyai 90110, Thailand

${ }^{2}$ The International Relations and Security Studies Programme and Senior Lecturer, University of Waikato, Hamilton, 3240, New Zealand

*Corresponding author. E-mail: kayaneechor@gmail.com

https://doi.org/10.12982/CMUJASR.2017.0008

\section{ABSTRACT}

The ongoing conflict in southern Thailand started in 2004 and has various deeply rooted causes. The Thai Government has tried many strategies to resolve the violent problem. However, it has been proven that physical and hardline measures alone cannot stop the conflict. Non-violent tools and public participation must be involved in any long-term solution. Peace polls and surveys are among the most popular tools for ascertaining local people's needs and perspectives. This article aims to describe the three peace survey projects conducted from 2016 to 2017, and to compare peace surveys in Thailand with peace polls in Northern Ireland where polling was successfully used as a peacebuilding tool. Active observation and in-depth interviews were employed in the research for this article. The results show that polling and surveying public opinion are very important for the peacebuilding process. Lessons learned from both Thailand and Northern Ireland show that people's participation and the involvement of the conflicting parties in peace surveys are very important for success.

Keywords: Peace poll, Peace survey, Peacebuilding, Southern Thailand 


\section{INTRODUCTION}

The ethno-religious conflict in the southernmost part of Thailand has been going on for more than a decade. Many thousands of lives, including both innocent civilians and government officials, have been lost since the resurgence of violence there in 2004 (Kaewnui, 2015). The conflict between the Thai Buddhist state and Muslim insurgent groups has a long historical background and complex multiple root causes. Although it does not capture the world's attention as much as other conflict cases in South-East Asia, almost daily violence occurs. Many factors and variables influence the tension between the conflicting parties. In the case of southern Thailand, ethnic tension has been latent in this sensitive area for centuries. The villagers in these conflict provinces have to live in fear, in an insecure atmosphere.

The hard-line approach conducted by the national security forces has failed to completely suppress the violence. It has been argued (Boonpunth \& Rolls, 2016) that resolving this chronic conflict requires time, patience and understanding. Indeed, the Thai government has shifted from its hard-line approach to one encompassing a peace process. Recently, there has been growing interest in conducting peace polls and surveys in order to ascertain local people's opinions.

\section{LITERATURE REVIEW}

Why is public opinion important in the peace process? According to Lederach's Pyramid (1997), grassroots or people in the communities are at the bottom as the base and the majority in the conflicting area. Conversely, a lower position increases the degree to which individuals directly experience the consequences of decision-making, but limits access to decision-making power (Lederach, 1997). Should peace be built from the top down, or from the bottom up? The "Peacebuilding Pyramid" helps answer this question by guiding peacebuilders to the appropriate approach because Lederach's Pyramid explains who acts on each level, and what actions are best taken at each level. The levels are: (1) the top leadership, (2) the middle-range leadership, and (3) the grassroots. The peacebuilding pyramid provides a simple way to describe the numbers of people involved at each level. The top-level elite leadership represents the fewest people, in some cases only a handful of key actors. The grassroots level, on the other hand, involves the largest number of people, who best represent the population at large. 
Peace polling has been conducted, and promoted as a peace process in countries such as Northern Ireland and the Philippines. It was said in an article 'Peace Poll' by Kaewnui (2015) that the experience of using peace polls in Northern Ireland encouraged the end of the conflict and helped lead to the 'Belfast Agreement' in 1998. Eight peace polls were conducted between 1996 and 2000 in support of the peace process in Northern Ireland, while the idea of surveying public opinion has just been recently initiated in the deep south of Thailand. However, in southern Thailand, peace polls have not been developed for official policy makers. There have been some attempts to conducted peace polls, but the results of the polls have not been integrated. In 2012, nine polls were conducted during Yingluck's government. ${ }^{1}$

The first poll was conducted after a peace dialogue had started between the Thai government and representatives of the resistance movement. The polls were organised by academic institutes in Bangkok including the National Institute of Development Administration (NIDA), the Suan Dusit Rajabhat University, the Center for Conflict Studies and Cultural Diversity, Hatyai University and Fatoni University (Chalermsripinyorat, 2017). However, these polls have limitations because the results from various organisations have not been integrated and have had littleimpact on policy makers.

As the past polls were not able to provide an answer or lead the country to a solution, in early 2015, King Prajadhipok's Institute started a peace-polling project to encourage people's participation in the peace process in the southernmost provinces. The Institute has cooperated with various sectors and networks including academics, NGOs, and the civil society sector. As part of the project, one of the researchers has been involved in the project from the beginning. This cooperation is significant since this is the first step in Thailand towards creating a peace survey as an extra tool to help to resolve the ethno-religious conflict in the south. Peace polling is still a new idea for Thai society, but it is not in those countries that have experienced creating and conducting peace polls. The peace poll project in Thailand has subsequently been called 'Peace Survey' after the meanings of peace polls and peace surveys have been defined. The methodology of the surveying project is important to ensure the result is reliable and trustworthy.

\footnotetext{
${ }^{1}$ Yingluck Shinawatra became the $28^{\text {th }}$ Prime Minister of Thailand from 2011 to 2014.
} 
The main purpose of the article is to promote the idea of the peace poll and survey as a tool that can help make the peace process more effective. It would be useful, therefore, if this article could encourage public participation in the peace process, or even be used by policy makers and relevant authorities to build a lasting peace in southern Thailand and other places as well.

\section{HISTORICAL CONTEXT}

\section{Peacebuilding efforts in Southern Thailand}

The southernmost provinces were known as the Malay Kingdom of Patani and considered a colony of Siam. In the past, Pattani was a centre for trade, as well as the centre of Islam. After the signing of the Anglo-Siamese Treaty in 1909, the Pattani Kingdom was reduced to a province under Thai rule. Tension between the Pattani region and the central state continued and was intensified after the state attempted to modernise the country by using the extreme nationalist policies. Finally, a Patani People's Movement was formed to resist these policies that were perceived by people as the state trying to destroy their Muslim identity. Furthermore, the local Muslim people feel they are denied access to state resources and cultural rights as these provinces are among the least developed regions of the country. The conflict also takes the form of militant attacks (e.g. ambush, bombing, arson) which aim to challenge directly the central government and seek the establishment of an independent state or some form of special autonomous region (Notholt, 2008).

A major milestone was achieved when the Thai government agreed to sign the general consensus document to launch a dialogue process for peace in the border provinces of southern Thailand, in Kuala Lumpur, February 28, 2013. Although it was just the beginning of a 'long process', it was the first formal open discussion (Sithraputhran, 2013). One of the major insurgency groups, Barisan Revolusi Nasional (BRN) had been involved in peace talks with the Thai government in 2013. However, the dialogue was expected to have wider insurgent representation, including groups such as Mara Patani ${ }^{2}$.

\footnotetext{
${ }^{2}$ Mara Patani (Patani Consultative Council (PCC)) is a loose umbrella group of six political liberation organizations in the deep south, including 1) BRN Action Group, 2) Barisan Islam Pembebasan Patani (BIPP), 3) Pertubuhan Persatuan Pembebasan Patani (PULO-P4), 4) Pertubuhan Pembebasan Patani Bersatu (PULO-dspp), and 5) Pertubuhan Pembebasan Bersatu (PULO-mkp) 6) Gerakan Mujahidin Islam Patani (GMIP).
} 


\section{Peace polls and peace surveys in Southernmost Thailand}

An important question to begin with is what are the differences between peace polls and peace surveys? Peace polling is a survey of public opinion undertaken with the collective participation of the parties to the negotiations (Irwin, 2012). Questions for peace polls should be concise and cover only a few issues. Therefore, surveying in Thailand is considered as a peace survey, not a peace poll, because the questionnaires are more to get general opinion about peace in the area, but do not finalise any peace decisions. Furthermore, peace polls need to have participation from all the relevant parties or stakeholders.

After a few discussions within the academic working team, the team agreed to call it a 'Peace Survey' project instead. It was first called a 'Peace Poll' because the idea of getting public opinion came from a peace poll carried out in Northern Ireland. The contexts of Northern Ireland and Southern Thailand are, of course, very different. The Southern Thailand case is not yet at the stage of making a decision on any peace issues. Therefore, the purpose of these surveys focused more on local people's opinions on the peacebuilding process and peace dialogue.

In early 2015, King Prajadhipok's Institute initiated the 'Peace Survey' project in order to encourage people's participation in the peace process in the deep south. The Institute has cooperated with fifteen groups in the south and Bangkok from various sectors and networks, including academics, NGOs, and civil society ${ }^{3}$. A fundamentally important question for the organisers was how could a peace survey be developed into a peace poll and then ultimately lead to active peacebuilding? A peace poll must be concise and concern few issues, whereas a peace survey helps to develop people working in the peacebuilding field by providing knowledge and information about good practices (Interview Respondent 5, 19 September 2016). Moreover, if peace surveys

${ }^{3}$ The fifteen networks are as follows: Faculty of Humanities and Social Sciences, Yala Rajabhat University; Faculty of Management Sciences, Prince of Songkla University; Faculty of Communication Sciences, Prince of Songkla University; Asia Foundation; Centre of Excellence in Mathematics, Faculty of Science, Mahidol University; Peace Resource Collaborative; Deep South Watch; Center for Conflict Studies and Cultural Diversity; Institute of Research and Development for Health of Southern Thailand, Prince of Songkla University; Institute of Peace Studies, Prince of Songkla University; Institute of Human Rights and Peace Studies, Mahidol University; Al-Salam Institute, Fatoni University; Islamic Academic and Arabic Studies, Princess of Naradhiwas University; Civil Society Council of Southernmost Thailand; Office for Peace and Governance, King Prajadhipok's Institute. 
have been conducted in an area, people will get used to the idea of peace and acquire knowledge at the local level (Interview Respondent 4, 19September 2016). The ability to conduct peace surveys, however, depends on the prevailing political situation at the time the survey is scheduled.

Once a survey has been conducted, how does it become apparent that a situation has been created which is conducive to a peace poll? In most cases, this will be when the parties to the conflict have determined what they want and recognised the importance of obtaining locals' opinions. A peace survey, therefore, should be viewed as 'something on the way' to conducting a peace poll. A peace survey helps villagers understand the concept of a peace process; when the needs of the conflict parties and the local people meet, a peace poll can be implemented as an extra tool to assist in furthering the peace process. This evolutionary approach received solid supported on the ground.

Respondent 2, for example, said we need to do this kind of survey again and again because it helps to create space that links and communicates among networks. We need to survey needs of villagers continuously to make them feel comfortable in expressing their opinions. (Interview, 19 September 2016).

Respondent 10 added that "we could see the trends of people's ideas in this conflicted area. It helps peacebuilders to be confident that they are heading in the right direction". (Interview, 6 October 2016). However, Respondent 9 saw that "surveying would help some, but the key to success more depends on government policy". (Interview, 9 October 2016).

\section{METHODOLOGY}

In-depth interviews and active observation techniques were employed to collect primary data. Data source triangulation was employed; this article makes use of both primary and secondary data to increase the credibility and validity of the findings. Ten representatives of the peace survey project team were interviewed. The researchers selected key participants, as they are part of the academic working team. This team played the central role of planning the project, designing the questionnaires, determining the methodology, analysing the data, and drawing conclusions. King Prajadhipok's Institute invited relevant 
authorities to join the project. Fifteen networks decided to join the project and assigned persons to be in charge of their participation. The key person interviews were conducted mostly in Pattani province in September and October 2016. The interviews were recorded and transcribed by the Thai researcher. A semi-structured interview guide was used to collect the data.

Active observation has been used in a variety of disciplines as a tool for collecting data about people, processes, and cultures in qualitative research. The Thai researcher was part of the peace survey projects from the end of 2015 until 2017 (Project I: February-March 2016; Project II: July-August 2016; and Project III: A pril-May 2017). As the Thai researcher was one of the academics working on the peace survey project team in the deep south, the researcher used active observation techniques to review the process of conducting the peace survey. This technique is very useful, especially during fieldwork because it allows for insight into contexts, relationships, and behaviour while the peace survey is conducted.

Secondary data included data from published books, academic journals, newspapers and articles. The documentary method was used as a supplement to the other research methods to make the research more complete. Finally, content analysis was used for analysing data from interview transcripts, active observation and, secondary sources.

\section{THE MAIN FINDINGS AND HIGHLIGHTS OF THE PEACE SURVEY PROJECTS}

These peace survey projects are, it can be argued, different from past ones in that the 15 networks agreed to survey public opinion in this region systematically and continuously. Moreover, the surveys were responsive to the real needs of the local people and were able to bring about a peaceful end to the violence (Kaewnui, 2017). Besides the significance of the cooperation among the 15 networks, the methodology of this project is also important. The project team paid close attention to the research methodology to make sure it had technical as well as political validity. Most of the team members satisfy the results as the surveys has prepared them for the future projects. Respondent 9 was very satisfied with the project performance because the surveys helped to promote and publicise the peace process. The following main findings show that the project series was unique, reliable, and acceptable to all parties. 
Networking. The reasons for the 15 leading organisations joining the peace survey projects were varied. Overall, most of them decided to be part of the projects because work on the peace process is one of their fields of interest. The projects, therefore, provided a valuable opportunity for them to learn and share.

Respondent 3 decided to join the projects because they had done similar surveys in these southernmost provinces and their experiences could help these projects be successful. "From our experience, these kinds of surveys were always questioned. People wondered whether the results of researches are biased or not", added Respondent 3. (Interview, 19 September 2016).

Respondent 2 believed that whoever wins the public wins the war, and people are questioning what villagers actually want. "To answer this question, we need to prove it by using the valid research methodology. The answers should be based on knowledge and data not feelings. Otherwise, conflicting parties claim that the ideas are from people without any proof".

Respondent 10 wanted to find out what the actual needs of the local people were and decided to use the idea of peace polls, as had been conducted in Northern Ireland. Respondent 8 joined the surveying team because he/she believed his/her specialised skills in research methodology and statistics would be useful to the projects. (Interview, 20 September 2016)

Although the networks are a good combination of academic institutions and civil society organisations, it is necessary to consider who is missing from these survey projects. The findings from the interviews were that:

...besides [the] conflicting parties (i.e. the government and the insurgent movement's leaders), [those] leaders respected by the locals should [also] be involved in the projects. For southernmost Thailand, they should be respected by the locals; for example, Provincial Islamic Committees, Academic Institutes and civil society groups (Interview Respondent 1, 19 September 2016).

Respondent 2 said that "four groups in particular should be included in the survey projects team: religious teachers, Tadika teachers, religious leaders and leaders of local administrative organisations." 
Most of the respondents agreed that one of the highlights of the projects was that participants from a wide range of institutions joined the project team. Working together among the 15 institutes, along with civil society groups, provided a good opportunity to share knowledge and build social capital. The result of content plus context plus process is academic flexibility (Interview Respondent 7, 20 September 2016). Cooperation from the civil society groups was very much appreciated. Moreover, collecting data on the fieldtrips is also another highlight of Respondent 10 , because it is interesting to hear stories or untold experiences from the locals.

Sampling and data collecting. Project research methodology is another highlight of the project. The team paid full attention to sampling and data collection. Data was collected through face-to-face interviews, using questionnaires to get information about the general characteristics of the population, as well as opinion leaders from all different sectors. The first survey was conducted between February and March 2016; the second one from July to August 2016; and the third one between April and May 2017. The survey area covered the provinces of Pattani, Yala, Narathiwat, and Songkhla (Chana, Thepa, Nathawee, and Sabayoi districts). Sampling methods, based on statistical probability, were used to ensure that all units within the population had the same likelihood of selection. Thus, the sample groups' representation validity would make the statistical errors of the survey results admissible (Peace Survey 2 Report).

The survey team used questionnaires compiled from relevant research studies such as the CSCD Peace Survey in 2015 and modified them to suit the characteristics of the sample groups of respondents. After discussions among the academic team, the survey questions were developed and classified into four parts.

Part 1: General Personal Information. This reflects the identity of local people and the communication channels that are the most popular among locals in this area.

Part 2: Attitude towards the problems and unrest in the region. This section asks about the insurgent situation and the reasons why people decided to join insurgent groups.

Part 3: Attitude towards the peace process. This section was concerned with attitudes toward the peace process pursued by the military government. The questions were designed to show how much confidence people have in the peace process, their perspectives on the unrest in the southernmost provinces, and how it affects the locals. This part shows how participants experience the conflict. 
Part 4: Attitude towards actions to be taken to transform the conflict. The final section was about ascertaining people's perspectives on the peace process and peace dialogues. This part includes the identification of priority issues and how to resolve the unrest.

Besides the well-designed methodology, fieldwork data collection teams were also an important factor in the peace survey projects' success. The fieldwork teams had five main roles and duties. The team members were all experienced in collecting data in the area and well-trained in interviewing. The following key persons were involved in the process of interviewing respondents:

A Fieldwork Manager was responsible for liaising between fieldwork supervisors and the academic team and facilitating the documentation work between supervisors and interviewers. The Fieldwork Manager was supported by Assistant Fieldwork Managers. The Fieldwork Supervisors oversaw the work of the interviewers in their respective areas, answering questions and addressing problems arising during the fieldwork and collecting and checking the thoroughness of the questionnaires compiled by the interviewers before they were then submitted to the Fieldwork Manager. There were almost 100 interviewers responsible for collecting the data. The Local Academic Team was in charge of overseeing the overall data collection process and obtaining the fieldwork data from the Fieldwork Manager for further action (Peace Survey 1 Report).

The ages of the sample groups were between 18-70 years. The sampling method was a highlight of this survey because the statistics guarantee that everybody has the right to be chosen. The surveys collected data by using questionnaires. The Field teams that had been trained in using these peace survey questionnaires interviewed the samples. The sampling area for the first peace survey covered 195 villages, 79 Tambons (sub-districts), and 36 districts. Eight families were randomly picked from each village and one person from each family was interviewed. The total sample was 1,560 surveys (Peace Survey 1 Report).

The second peace survey covered 131 villages, 123 Tambons, and 37 districts. This time, 12 families were randomly picked from each village and one person from each family was interviewed. The total sample was 1,572 surveys (Peace Survey 2 Report).

The third peace survey was slightly different from the previous two because it also sampled opinion leaders, defined as the leaders of local administrative authorities. 
The Peace Survey 3 Report has not been officially published yet, but the total sample was 1,840 surveys and included 1,583 villagers and 257 opinion leaders. The villagers tended to be more female than male, while for the opinion leaders the opposite was the case. Most of the interviewees self-identified as Muslim, which reflected the fact that their identity was based on religion rather than nationality or history. Almost 90 percent of the villagers sampled could communicate in the Thai language. The highest education of the villagers was primary school, while for the opinion leaders it was Master's degrees. The occupations of most people were agriculture, fishery, and animal husbandry, although the majority of opinion leaders were religious leaders or religious teachers.

The impact of the peace survey projects. First, these surveys reflect the perspectives on the violence of people in the area (Peace Survey 2 Report). The issues that concerned people the most are economic ones, especially employment and income. It was also evident that people do not feel safe travelling at night. Noticeably, more than 50 percent of people indicated that they have to be careful when they communicate with other people. The survey results also make it abundantly clear that trust is still a sensitive issue in the south. Perspectives on the fairness of government policies and measures show that both civilians and opinion leaders agree that the justice process treats Thai Buddhists more fairly than Muslims. However, Muslims have more freedom than Thai Buddhists in pursuing religious activities. Politically, males play a more important role than females while there is greater equality in economic and peacebuilding aspects. When asked why people turned to insurgent groups, most respondents thought it was due to social reasons such as drug addiction and low education levels.

Second, the survey results have shown which issues are most sensitive to the locals. There were some questions that people avoided answering by choosing 'do not know' or 'do not want to answer'. Silence has meaning in sensitive areas like the deep south. Interestingly, people avoided answering some questions or expressing their opinions on some issues: for example, independence, choosing sides, autonomy, and the militant group. The five question areas in which people tended not to answer were: 1) accepting Mara Patani as the representative of resistance movements in the peace dialogue; 2) the rights of Malayu Patani on this land; 3) accepting foreign parties' involvement in the process of peace dialogue; 4) paroling prisoners convicted in security related cases in order to create a better atmosphere for peace dialogue; and 5) 
proposing peace dialogue as a national agenda (Peace Survey 1 Report). The silence that occurred in respect of these question areas means local people do not want to answer or are scared to voice their opinions. If Thailand wants to conduct peace polls in order to reduce the conflict in the south, it must work out how best to obtain the opinions of the locals.

Lastly, public opinion collected by the peace survey projects has been distributed to key national policy makers such as the Prime Minister, the Ministry of Interior, the National Intelligence Agency, the Office of the National Security Council, and the Internal Security Operations Command. Policy implementers, such as Provincial Governors and local security authorities, have also been informed of the results of the projects. The universities, as well as the mass media, have also received the peace survey project reports. Moreover, the findings have been presented to the peace dialogue representative teams from both the government and the insurgent movement ${ }^{4}$. The survey findings would be considered as their inputs for the next round of peace dialogue. This is a good sign of democracy in approaches to resolving the conflict in the deep south, as public participation and people's opinions have been brought to the attention of the relevant authorities. After the first peace survey project finished, the survey teams organised a 'Peace Survey Press Conference' on 17 May 2016, at Prince of Songkla University, Pattani campus. The event was acknowledged by the press, featured on a popular television news programme, and was shown live on the Deep South Watch website (Three Miti News Programme, 2016).

\section{LESSONS LEARNED FROM THE PEACE SURVEYS I, II AND III}

As has been noted already, Northern Ireland is one of the models for using polls in a peace process. There are, of course, differences among countries faced with such conflicts. The increasing conflict in Northern Ireland led to people wanting to use peace polls as a tool in the conflict. Northern Ireland is certainly very different from the southern Thailand case where locals keep quiet and refuse to speak up (Interview Respondent 5). Moreover, the conflict in Northern Ireland

\footnotetext{
${ }^{4}$ An official letter dated 3 August 2017 concerning progress report on distribution the result of the peace survey projects from the King Prajadhipok's Institute to the heads of 15 networks who joined the peace survey projected.
} 
was fueled by religious differences between Protestants and Roman Catholics whereas in the case of southern Thailand there is not only the religious factor, but also language and way of life. This section of lessons learned has been concluded by comparing Irwin's Northern Ireland works and the researcher's experiences in southern Thailand.

Lesson 1 - The formation of a contact group and the participation of conflicting parties to help resolve the conflict. In Northern Ireland, the research was undertaken by a group of academics at Queen's University of Belfast. Political parties were then invited to participate in the drafting of the poll. Finally, an independent sponsor joined the team (Irwin , 2012).

In Southern Thailand, the peace survey was based on cooperation among academics from both local and centrally based universities. Moreover, in the process of drafting the questions, representatives from civil society, foundations the media, the security authorities and public administration sectors were involved. The variety of attendees made the survey project reliable and acceptable nationally. This is a good sign. Colin Irwin has commented that generating involvement from the media and political parties, as well as obtaining funding and having universities designing and running a series of public polls is best practice peace making (Irwin, 2012). Most respondents to the Thai peace surveys also thought that such this cooperation was one of the main advantages of the projects.

Although it was accepted that participation from civil society and local people is very important, the opinions of conflicting parties are also central (Deep South Watch, 2013). The lesson learned from the Northern Ireland case is that all the relevant parties should be invited to join the researchers' team. Conflicting parties should assign representatives to work with the team in order to plan and design a series of public opinion polls with the objective of assisting the parties with their negotiations (Irwin, 2012). The important thing for conducting a peace poll in the future is making sure that the poll does not just serve one of the conflict parties. Partisan polling could create more problems and fail to help to resolve the conflict. In Northern Ireland, many politicians disagreed with much of what was done in the poll because they thought some important issues were ignored or bias existed (Irwin, 2012). In the case of Thailand, it was not possible to invite any of the conflicting parties' representatives to join at the stage of survey design because the parties to the conflict have not all been officially identified. The methodology employed in Thailand, unlike that in Northern 
Ireland, did not receive complaints it could be improved in terms of the way the questions were asked (Irwin, 2012).

In the introduction to the polling interview it should be clearly stated who is doing the research, who is funding it and who will get the results (Irwin, 2012). In both Northern Ireland and Thailand, it was made sure that it was clear who had organised the survey and the confidential nature of the results was also stressed.

Prioritising the elements of a conflict and a solution is also important. Normally, neither party to a conflict will take the issues and concerns of other party seriously. It is necessary, therefore, to have all the parties to a conflict list the elements of the conflict as seen from their point of view, in mutually acceptable neutral terms and test them against public opinion to see which issues are genuine concerns of the respective communities and which are not (Irwin, 2012). Politicians like to make peace deals because it can help win elections. For every element of the conflict raised as a concern, ask the parties to propose a potential solution (Irwin, 2012).

Lesson 2 - Developing common and neutral terms for use in the survey. Most people who have experience in peace survey projects agree that the choice of words is very sensitive, and therefor an important part of the process. Choosing the right word is one of the first stages because using the wrong words can cause bias among the communities. This is why the peace survey project was very concerned with word choice. The questionnaires were considered by civil society networks invited to do so by the academic team to try to avoid misunderstanding and bias. For example, the most basic words like 'santipap' ${ }^{5}$ and 'santisook' ${ }^{6}$. Wording in the questionnaires cannot be too academic either because villagers will not understand them.

During a conflict anywhere, the language of political terms within each community can produce distinctive meanings that are part of their different identities (Irwin, 2012). To come up with the questionnaire for the Northern Ireland polls, all the relevant parties needed to agree to the questions in the survey. Both sides had to adjust their political rhetoric,

\footnotetext{
${ }^{5}$ 'santipap' is a Thai word used in the conflict area where political ideals are different. The conflict might end up with wars. (https://www.deepsouthwatch.org/node/6601) ${ }^{6}$ As defined by the Thai government, 'santisook' means that the government does not discuss politics but focuses on building trust. Another main purpose is to find solutions for the conflict, considered to be an internal issue, and there is no war counterpart. (https://www.deepsouthwatch.org/node/6601)
} 
at least for the purposes of an agreement. The Northern Ireland experience shows that obtaining agreement from all the relevant parties is important but can take time. Besides religious and cultural issues, language is one of the main differences between local people in the deep south. The state is very careful in using terms for describing the situation or the insurgent groups in the south. The peace survey team realised the importance of using the right terms as well. There are many kinds of expression referring to people that have tension relating to political identity attached to ethnicity. It was found that there are angles related to, for example, referring to Thai Muslims as being different from Malay Muslims. The Thai state seems to accept a religious difference rather than allow ethnic characteristics to be the outstanding difference from being Thai. Thus, being a Thai citizen that adheres to Islam is seen to create less of a problem than accepting the way of life of the Malay (Panjor, 2017). Some examples of problematic political terms are what to call these three southernmost provinces, how to describe the ongoing situation, and the militant groups, and how to define peace itself.

- The land of the southern border provinces. The first problem is using the right term is what to call the three southernmost provinces. The name for this land has constantly changed. There was a question in the peace survey asking what to call these three provinces and the four districts in Songkhla province. In the Peace Survey II, the choice of Langkasuka ${ }^{7}$ was eliminated because nobody chose this one in the first survey. This shows that people do not pay much attention to history. They like to call this region, as they are named, 'Pattani, Yala, Narathiwat and four districts of Songkhla'. The other choice that received a high score was 'the southernmost provinces'. 'Patani' is a sensitive term and means that the locals are on the opposite side of the government.

From the insurgent movement's perspective, however, the Malay term 'Patani' is used to refer to this area as well as the Arabic term 'Fatoni'. These terms have different political and cultural meanings that describe a politically independent entity with a narrative of its origins and individuality not dependent on the centre in Bangkok (Panjor, 2017). At present, the official term is 'Southern Border Provinces'. This is referred to in law (The Southern Border Provinces Administration Act) as covering five provinces (including Pattani, Yala, Narathiwat, Songkhla and Satun), but in terms of security operations it is limited just to the three provinces and the four districts of Songkhla (Panjor, 2017). ${ }^{7}$ Langkasuka is a term referring to an early Malay Kingdom. 
- The ongoing conflict situation and the militant groups. The Thai state is very careful about labelling the situation in these areas because it is a sensitive issue for both security and international reasons. The term used can reflect the seriousness of the situation, which might affect Thailand's international relations. The public calls groups of people who use weapons to fight with state officials differently. Using the wrong term often causes trouble, as happened during the Thaksin administration ${ }^{8}$. He described the militant groups as 'southern bandits' and since then the violence has flared up.

Thai officials have begun to understand the insurgency better recognising that its characteristics are local, rather than being shaped by outside factors or agents that what they were facing. This has more local characteristics than those of an international movement. The term used to describe people who have different opinions and ideologies from those of the state was consistently changed to 'insurgents'. After the coup in 2006, the consensus assessment of official Thai agencies was that the armed insurgents causing the unrest actually had the goal of seceding. Not long after that, however, international political and legal analysis, pushed by experts in the Ministry of Foreign Affairs, advised caution when using terms to label the situation and the opposition, because the situation risked being raised to an international issue with the possible consequences that it could lead to intervention by international parties. Around 2009, Thai government agencies determined that the terms used to refer to this situation could create complexities: using the term 'terrorism' may attract the attention of major powers and encourage international terrorist organisations to become involved. While admitting that the situation was one of 'unrest', they would call the other side 'groups causing unrest', which may define the situation as one of 'armed conflict'. The influential proposal of the Ministry of Foreign Affairs, which later became the control point for the Thai side for many years, was to avoid directly admitting that the opposition group was an established organization of any sort, with a clear structure or chain-ofcommand, and without any code of conduct about the use of force or capability to engage government forces. For this reason, the Thai state is reluctant to affirm or accept the existence of the BRN 9 . Since the end of

${ }^{8}$ Thaksin Shinawatra was the $23^{\text {rd }}$ Prime Minister of Thailand, during 2001-2006.

${ }^{9}$ BRN stands for Barisan Revolusi Nasional which means 'National Revolutionary Front'. It is a Patani independence movement in northern Malaysia and Patani, southern Thailand. As of 2017, it was claimed to be the most powerful rebel group in the region. 
2009, the terms used to refer to the armed opposition to the state clearly changed from 'insurgents' to 'perpetrators of violence' (Panjor, 2017).

- The definition of the end of the conflict. In Thai, peace can be translated into two words: 'santiparb' and 'santisook'. The Thai state wants to use 'santisook' more than 'santiparb'. However, the surveys show that people prefer the term 'santiparb' to 'santisook'. Even the peace dialogue has changed its name from 'santisook' to 'santiparb'. The reason for this is that the peace dialogue aims to create peaceful lives for people in the area, not for political purposes or to create an autonomous region (Isranews Agency, 2014). The next turning point for change came after the peace talks between the Thai state and militant representatives commenced (Kerdphol, 2016). The dynamics of the terms related to finding an end of the conflict were interesting. The changes in identifying words and terms are related to attempts by the Thai state to specify the Thai government's understanding of the armed movements. Under previous governments, official Thai policy documents stated that the solution that was being negotiated was 'peace'. The present government changed the target of peace negotiations to 'happiness': a word whose meaning was defined according to the needs of the state, because from the perspective of the security forces, the word 'peace' is an international issue and the meaning is too universal. By using the word 'peace', it was assumed that it would attract the attention of international actors and create concern that the direction of the peace dialogues could not be controlled. It was believed that changing the goal to 'happiness' makes it unrelated to a situation of war or armed conflict, and frames the conflict as a domestic one (Panjor, 2017).

Experience shows that choosing the right words or terms in this sensitive area is very important. To make sure that the survey questions are less likely to produce biased results, that could prejudice the outcome of the research, partisan terms have to be replaced by acceptable neutral terms.

\section{Lesson 3 - Establishing trust and confidence in the peace process.} A lesson learned from Northern Ireland was that a lack of communication could cause a lack of trust. Conflicting parties engaged in hostilities do not give up violence in favour of political negotiations because they often do not trust the other parties will negotiate in good faith and believe the peace talks are only tactical (Irwin, 2012). Establishing independent, reliable and confidential lines of communication between the relevant 
parties with points of access to other independent third parties who can provide expert advice is required (Irwin, 2012). After years of violence in Northern Ireland, the continuation of the conflict and the failure of the state's policies to bring the conflict to an end, meant that many people did not have confidence that a ceasefire agreement would be any more successful than all the failures of the past (Irwin, 2012). Public opinion polls must deal with all the problems and possible solutions to a conflict. Furthermore, continued progress towards peace should also be addressed by asking people what they want. Questions that should be asked, for example, must concern a state peace agreement, an end to violence, negotiations to be started, timely decisions to be made, democratic institutions to be re-established, the maintenance of human rights standards and the rule of law, effective policing acceptable to the whole community and economic development in the context of peace and so on (Irwin, 2012).

In the Thai peace survey projects, the surveys also asked what concerned people about the peace talks. Most of them answered that they were concerned that the peace dialogues between the representatives of the Thai state and resistance movement would benefit only one party (Peace Survey 1 Report). One difficulty in building trust and confidence in the case of Thailand is discontinuity because the Thai government keeps changing the representatives in, or the leaders of, the peace dialogue team.

The peace survey asked people how confident they were about the peace talks. Not even half of people surveyed believed that the peace talks would lead to an end of the conflict (Peace Survey 2 Report). The peace surveys, however, do provide knowledge about peacebuilding to local people and need to be repeated. These surveys will create an atmosphere of peace in the region.

\section{RECOMMENDATION}

The following recommendations for research are based on the study findings:

The introduction of the peace survey should clearly state to the respondents who is organising the survey, who is funding it, who will get the results, and the confidential nature of the results.

Choosing the right words for the survey questions is very important and sensitive because using the wrong words can cause bias among the communities. Partisan terms have to be replaced by acceptable 
neutral terms to make sure that the survey is less likely to produce biased results.

Furthermore, building trust and confidence is one of the most essential factors for peacebuilding. A lack of communication could cause a lack of trust; therefore, local people's opinions should be surveyed on an ongoing basis. Peace surveys can enhance understanding among local people in the deep south and as well as peopleoutside the conflictarea.

Finally, data sets from the peace surveys should be further studied in all specific areas of expertise, as these data are the most valuable for policy makers, helping them see trends, understand relationships among relevant factors, and consequently meeting the local's needs.

\section{CONCLUSION}

Although the peace poll and survey projects in southern Thailand cannot make any significant changes immediately, these projects do help in providing knowledge about the peace process to the local people who have learned to try to handle the violence by peaceful methods. Hopefully, these projects will create a culture and atmosphere of sharing opinions and expressing feelings among stakeholders. These three surveys not only help reveal the opinions of the local people, but also help to develop people who work in the peace process network. Both the project teams and the locals, therefore, are learning and developing together. In Northern Ireland, there were eight peace polls within four years to finalise the peace agreement, although clearly the contexts of Northern Ireland and southernmost Thailand are different. Peace polling alone cannot create any peace agreements or encourage ceasefires. However, polling or surveying can be useful in building trust and confidence in the conflict area as it shows that people's opinion has been acknowledged and encouraged. Ideally, peace polling, together with the progress of peace dialogues, need to proceed in tandem in the case of the southernmost provinces in Thailand.

\section{ACKNOWLEDGEMENTS}

This work was supported by the SAHPE-SEA Grant 2016: Strengthening Human Rights and Peace Research Education in ASEAN/Southeast Asia. 


\section{REFERENCES}

Boonpunth, K.C. \& Rolls M.G. (2016). The role of civil society in peacebuilding in southern Thailand. Journal of Public Affairs, 16(4): 376-383. https://doi.org/10.1002/pa.1598

Chalermsripinyorat, R. (2017). Peace poll: The comparison studies of the conflicts in northern Ireland and Southern border provinces of Thailand. In Thai. Bangkok: PRC.

Deep South Watch. (2013). Assessing the beginning of Patani general consensus on peace dialogue process. In Thai. Retrieved from https://www.deepsouthwatch.org/th/node/ 4014.

Irwin, C. (2012). The people's peace process in northern Ireland. CA: Palgrave Macmillan.

Irwin, C. (2012). 20 Peace lessons from northern Ireland to Israel and Palestine. Create space independent publishing platform. Isranews agency. In Thai. Retrieved from https://www. isranews.org/south-news/south-slide/item/31925talk_31925.html.

Isaranews Agency. (2014). Peace talk from santipap to santisook. In Thai. Retrieved from https://www.isaranews.org/south-slide/item/ 31925-talk_31925.html.

Kaewnui, S. (2015). Peace poll. In Thai. Retrieved from http://www. deepsouthwatch.or//node/7182.

Kaewnui, S. (2017). Peace survey. In Thai. Retrieved from http://www. deepsouthwatch.or/ds/10024.

Kaewnui, S. (2017) Situation in the southernmost provinces. In Thai. Retrieved from http://www.deepsouthwatch.org/node/10037.

Kerdphol, A. (2016). Peace talk for southern Thailand. In Thai. Bangkok: Office of the Secretariat of Thai Peace Dialogue.

Lederach, J.P. (1997). Building peace: Sustainable reconciliation in divided societies. Washington, D.C.: United States Institute of Peace Press.

Notholt, S.A. (2008). Fields of fire, an atlas of ethnic conflict. London: Stuart Notholt Communication Ltd.

Panjor, R. (2017). The politics of wording in the deep south. Retrieved from https:// www.prachatai.com/english/node/6692

Peace survey 1 report. (2016). Bangkok. Kong Rao. In Thai.

Peace survey 2 report. (2016). Bangkok: Kong Rao. In Thai. 
Sithraputhran, S., \& Grudings, S. (2013). Thailand agrees to talks with southern Muslim rebels. Reuters. Retrieved from https:// www.reuters.com/article/us-thailand-south/thailandagrees-to-talks-with-southern-muslim-rebels-id USBRE91R05820130228?feedType $=$ RSS\&feedName $=$ topNews Three miti news programme. (2016, 14 May). Channel 3. In Thai. 